\title{
1981 年度国産乗用車のオクタン価要求值調査結果
}

\author{
石油学会製品部会ガソリン分科会オクタン価要求值専門委員会
}

本調査は 1981 年型国産乗用車のオクタン価要求值分布を把握することを目的とし, 石油連盟の依頼により実施さ れた。試験はJPI-6 R-6-77 に準拠し, 低速法でのオクタン価要求值分布を正標準燃料および全沸点型標準燃料（混 合系）の計 2 種で, 試験車 15 車種 120 台を対象に実施した。統計は 1980 年度の調査結果のうち仕様変更なく引 き続き販売されている 15 車種 97 台を加えて処理した。その結果, 正標準然料に和ける低速法オクタン価要求值分 布は 50 および $90 \%$ 充足率でそれぞれ 90.0 および 94.7 オクタンであった。これは前年度に比べ，50および $90 \%$ 充足率で 0.2 0.3 オクタンとわずかに低い值を示した。

\section{1. 緒言}

本調査は国産乗用車のオクタン価要求值を把握する目的で, 石油連盟の委託により 1959 年に調査を開始し，本年度で 23 年目を迎えた。この間，レギュラー級ガソリンの無鉛化や自動 車排出ガス規制の強化が実施され，最近では自動変速機付き乗 用車の急激な 普及および 資源の 有効利用のため「省エネルギ 一」による然費改善基準（昭和 60 年度達成目標）の施行など 自動車をとりまく環境も年々変化してきている。本年度は試験 車 15 車種 120 台を選定し, 石油学会規格 JPI-6 R-6-77 才 クタン 価要求值測定法基準に 準拠して 試験を実施した ${ }^{\dagger 1)},{ }^{2)}$ 。 以下にその結果を報告する。

\section{2. 試 験 車}

試験車として 1981 年型の新型車または新造車の中から比較
的登録台数比率の高い15 車種 120 台を選定した。このらち 47 台は自動変速機付き車で, 7 台はターボチャージャ付き車 である。なお, 試験車の調達に際しては ORI（オクタン価要求 值増加）などを考慮してカーボン落し後の走行距離が 6,000 $\mathrm{km}$ 以上の車を選定した。

本年度のデータ集計は, 本年度試験車 120 台に 1980 年度 試験車のらち仕様変更がなく, 引続き販売されている車で本年 度の対象車種になっている 15 車種 97 台1)の結果を加えた合 計 15 車種 217 台の結果を統計的にまとめたものである。こ れらの試験車の車種名, エンジン型式を Table 1 に示す。

\section{3. 標 準 燃 料}

\section{1 正標準燃料 (Primary Reference Fuel ; PRF)}

イソオクタンと $n$-ヘプタンの混合により調製した。

Table 1 Test Vehicles and Engine Types

\begin{tabular}{|c|c|c|c|c|}
\hline Vehicles & Engine Types & 1981 & $\begin{array}{l}\text { of Cars Tested } \\
1980\end{array}$ & Total \\
\hline $\begin{array}{l}\text { Cedric } \\
\text { Laurel }\end{array}$ & $\begin{array}{l}\mathrm{L}-20, \mathrm{~L}-20 \mathrm{E}, \mathrm{L}-20 \mathrm{ET} \\
\mathrm{L}-20 \mathrm{~S}, \mathrm{~L}-20 \mathrm{ET}, \mathrm{Z}-18 \mathrm{E}\end{array}$ & 9 & 7 & 16 \\
\hline Skyline & L-20E, L-20ET, L-20, Z-20E, Z-18 & 8 & 8 & 16 \\
\hline Violet & $\mathrm{Z}-16, \mathrm{~A}-14$ & 3 & 7 & 10 \\
\hline Bluebird & $\mathrm{Z}-16, \mathrm{Z}-18, \mathrm{Z}-18 \mathrm{ET}$ & 9 & 8 & 17 \\
\hline $\begin{array}{l}\text { Sunny } \\
\text { Pulsar }\end{array}$ & $\begin{array}{l}\mathrm{A}-13, \mathrm{~A}-15 \\
\mathrm{~A}-14, \mathrm{E}-13\end{array}$ & 12 & 8 & 20 \\
\hline Grown & $\begin{array}{l}\text { A-14, E-13 } \\
\text { M-EU }\end{array}$ & & & \\
\hline Cresta & IG-EU, 13T-U & 8 & 5 & 13 \\
\hline $\begin{array}{l}\text { Soarer } \\
\text { Mark II }\end{array}$ & $\begin{array}{l}\text { IG-EU } \\
\text { IG-EU, } 13 \mathrm{~T}-\mathrm{U}\end{array}$ & & & \\
\hline Cheicer & 21R-U, 13T-U & 8 & 4 & 12 \\
\hline Gorona & $12 \mathrm{~T}-\mathrm{U}, 13 \mathrm{~T}-\mathrm{U}$ & 7 & 1 & 8 \\
\hline Carina & 3T-EU, $12 \mathrm{~T}-\mathrm{U}$ & 0 & 0 & 10 \\
\hline $\begin{array}{l}\text { Celica } \\
\text { Gamry }\end{array}$ & $\begin{array}{l}\text { 3T-EU } \\
\text { 21R-U, 3T-EU, 12T-U, 13T-U }\end{array}$ & 9 & 9 & 18 \\
\hline Starlet & $4 \mathrm{~K}-\mathrm{U}$ & 8 & 9 & 17 \\
\hline $\begin{array}{l}\text { Corolla } \\
\text { Sprinter }\end{array}$ & $\begin{array}{l}3 \mathrm{~A}-\mathrm{U}, 4 \mathrm{~K}-\mathrm{U} \\
4 \mathrm{~K}-\mathrm{U}\end{array}$ & 10 & 8 & 18 \\
\hline Galant & G-63BT, G-32B & 8 & 4 & 12 \\
\hline $\begin{array}{l}\text { Lancer } \\
\text { Mirage }\end{array}$ & $\begin{array}{l}\text { G-12B } \\
\text { G-11B }\end{array}$ & 4 & 8 & 12 \\
\hline Givic & EJ & 7 & 5 & 12 \\
\hline $\begin{array}{l}\text { Accord } \\
\text { Familia }\end{array}$ & $\begin{array}{l}\text { EK EP } \\
\text { E3, E5 }\end{array}$ & 10 & 6 & 16 \\
\hline
\end{tabular}

昭和 57 年 7 月 19 日受理

†1) 改質系標準燃料については過去 3 年間のオクタン価要求值調査で全沸点型標準燃料間の差がほとえど見られないため，本年 度は実施しなかった。

†2） 1975 年以来高速法オクタン価要求值調査を実施してきたが，いずれの年度も低速法オクタン価要求值より低い值を示して きた。また，低速法の測定範囲が高速法の測定範囲にわたっているととなどから本年度は高速法の測定を実施しなかった。 
Table 2 Full Boiling Range Reference Fuel

\begin{tabular}{c|c|c|c|c}
\hline \multirow{2}{*}{ Type } & $\begin{array}{c}\text { Range of Octane } \\
\text { Number }\end{array}$ & High Octane Number & Low Octane Number & Supplemental \\
\cline { 2 - 5 } Mixed Type & $70 \sim 94$ & $\begin{array}{l}\text { Mixture of 60\%, Reformate } \\
\text { L't Naphtha and 40\% } \\
\text { Cracked Naphtha }\end{array}$ & Straight-Run Naphtha & - \\
\cline { 2 - 5 } & $95 \sim 100$ & - & Toluene \\
\hline
\end{tabular}

Table 3 The Properties of Blending Stocks

\begin{tabular}{|c|c|c|c|c|}
\hline Test Item & Cracked Naphtha & Reformate Naphtha & L't SR Naphtha & Toluene \\
\hline Sp. Gr. $15 / 4^{\circ} \mathrm{C}$ & 0.7217 & 0.7983 & 0.6585 & 0.8711 \\
\hline $\begin{array}{l}\mathrm{R} . \mathrm{V} \cdot \mathrm{P} \cdot \mathrm{kg} / \mathrm{cm}^{2} @ 37.8^{\circ} \mathrm{C} \\
\text { Distillation (\% \% }\end{array}$ & 0.705 & 0.370 & 0.770 & 0.090 \\
\hline I. B. P. ${ }^{\circ} \mathrm{C}$ & 35.5 & 44 & 36 & 108.5 \\
\hline $10 \%$ & 47.5 & 81 & 45.5 & 110.7 \\
\hline $50 \%$ & 83.5 & 129.5 & 53 & 110.7 \\
\hline $90 \%$ & 154 & 153.5 & 74 & 110.8 \\
\hline $95 \%$ & 166 & 163.5 & 81.5 & 110.8 \\
\hline E. P. & 180 & 179 & 95.5 & 111.3 \\
\hline Recovery & 98.0 & 98.0 & 98.0 & 99.5 \\
\hline Residue & 0.5 & 1.0 & 1.0 & 0.5 \\
\hline FIA Analysis : & & & & \\
\hline Saturate & 47.9 & 48.5 & 98.8 & \\
\hline Olefine & 37.4 & 0.1 & 0.0 & \\
\hline Aromatic & 14.7 & 51.4 & 1.2 & \\
\hline Octane No. Research Method & 93.3 & 97.4 & 65.9 & \\
\hline Motor Method & 80.4 & 86.5 & 64.4 & \\
\hline
\end{tabular}

Table 4 Acceleration Method

\begin{tabular}{c|c|c|l}
\hline Acceleration Method & Type of Transmission & Initial Speed at Acceleration & \multicolumn{1}{|c}{ Throttle Condition } \\
\hline \multirow{3}{*}{ Low Speed Acceleration } & Manual & $1,000 \mathrm{rpm}$ & Wide Open Throttle (WOT) \\
\cline { 2 - 4 } & Automatic & $30 \mathrm{~km} / \mathrm{hr}$ & Part Throttle (PT) \\
\cline { 2 - 4 } & & & Detent Acceleration \\
\cline { 2 - 3 } & & & Part Throttle \\
\hline
\end{tabular}

\section{2 全沸点型標準燃料}

全沸点型標準燃料として無鉛混合系標準燃料を用いた。この 標準然料の調製は Table 2 に従った。

また，調製に用いたそれぞれの基油の一般性状を Table 3 に示す。

\section{4. 試験方 法}

試験は石油学会規格 JPI-6 R-6 -77 に準拠して行った。な お，加速条件は Table 4 に示す条件で行った。

\section{5. 試 験 場 所}

試験は主として参加機関の保有するシャシーダイナモメータ 一を用い，一部を日本自動車研究所のテストコースで実施し た。

\section{6. 試験結果および考察}

\subsection{1 年型全車のオクタン価要求值}

1981 年型全車のオクタン価要求值分布は, 本年度試験車 120 台に 1980 年度試験車のうち 15 車 種 97 台を加えた 15 車種 217 台の結果をもとに, 石油学会規格 JPI-6 R- 2 -72 オ
クタン価要求值分布推定法基準によって求めた。なお，正標準 燃料の絞り弁全開加速条件での車種別オクタン価要求值測定結 果を Table 5 に, 混合系標準燃料の測定結果を Table 6 に それぞれ示す。

1981 年型全車の低速法オクタン価要求值分布を Fig. 1 に 示す。また，この図より求めた 1981 年型全車の 10,50 少よ び 90\% 充足率におけるオクタン価要求值分布は Table 7 に 示すとおりである。

正標準燃料絞り弁全開加速条件でオクタン価要求值分布を 1980 年型全車と比較し, Fig. 2 に示す。

この図が示すように 1981 年型全車は 1980 年型全車に比べ 低い值になっている。

また, 最近 5 年間の年型全車における低速法オクタン価要求 值分布を Table 8 に示す。

\section{$6 \cdot 2$ 排気量別オクタン価要求値}

1981 年度試験車 $\left.{ }^{\dagger 3}\right)$ の排気量を 3 区分 $(1,300 \mathrm{cc}$ 以下, 1,301 $\sim 1,600 \mathrm{cc}$ および $1,601 \sim 2,000 \mathrm{cc}$ ) にして求めた排気量別才 クタン価要求值分布の 10,50 および $90 \%$ 充足率における才 クタン価要求值を Table 9 に示す。

†3）本年度試験車 120 台に前年度試験車 97 台を加えてまと めたもので登録台数比率は加重していない。 
Table 5 Low Speed Octane Number Requirements Distribution

\begin{tabular}{|c|c|c|c|c|c|c|c|c|c|c|c|c|c|c|c|c|c|}
\hline \multirow{2}{*}{$\begin{array}{c}\text { ONR } \\
\text { Research }\end{array}$} & \multicolumn{15}{|c|}{ Car Model Code } & \multirow{2}{*}{ Total } & \multirow{2}{*}{$\begin{array}{c}\text { ONR } \\
\text { Research }\end{array}$} \\
\hline & $\mathrm{A}$ & $\mathrm{B}$ & $\mathrm{C}$ & $\mathrm{D}$ & $E$ & $F$ & G & $\mathrm{H}$ & I & $\mathrm{J}$ & $\mathrm{K}$ & $\mathrm{L}$ & $\mathrm{M}$ & $\mathrm{N}$ & $\mathrm{O}$ & & \\
\hline $\begin{array}{l}\text { Teess } \\
\text { than }\end{array}$ & & & & & & & & & & & & & & & & & $\begin{array}{ll}\text { Tess } & \\
\text { than } & 70.0\end{array}$ \\
\hline 70.5 & & & & & & & & & & & & & & & & & 70.5 \\
\hline 71.0 & & & & & & & & & & & & & & & & & 71.0 \\
\hline 71.5 & & & & & & & & & & & & & & & & & 71.5 \\
\hline 72.0 & & & & & & & & & & & & & & & & & 72.0 \\
\hline 72.5 & & & & & & & & & & & & & & & & & 72.5 \\
\hline 73.0 & & & & & & & & & & & & & & & & & 73.0 \\
\hline 73.5 & & & & & & & & & & & & & & & & & 73.5 \\
\hline 74.0 & & & & & & & & & & & & & & & & & 74.0 \\
\hline 74.5 & & & & & & & & & 1 & & & & & & & 1 & 74.5 \\
\hline 75.0 & & & & & & & & & & & & & & & & & 75.0 \\
\hline 75.5 & & & & & & & & & & & & & & & & & 75.5 \\
\hline 76.0 & & & & & & & & & & & & & & & & & 76.0 \\
\hline 76.5 & & & & & & & & & & & & & & & & & 76.5 \\
\hline 77.0 & & & & & & 1 & & & & & & & & & & 1 & 77.0 \\
\hline 77.5 & & & & & & & & & & & & & & & & & 77.5 \\
\hline 78.0 & & & & & & & 1 & & & & & & & & & 1 & 78.0 \\
\hline 78.5 & & & & & & & & & & & & & & & & & 78.5 \\
\hline 79.0 & & & & & & & & & & & & & & & & & 79.0 \\
\hline 79.5 & & & & & & 1 & 1 & & & & & & & & & 2 & 79.5 \\
\hline 80.0 & & & & & & 1 & & 1 & & & & & & $\ldots$ & & 2 & 80.0 \\
\hline 80.5 & & & & & & & & 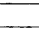 & & & & & & & & & 80.5 \\
\hline 81.0 & & & & 1 & & 1 & & 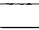 & & & 1 & & & & & 3 & 81.0 \\
\hline 81.5 & & & & & & 1 & 1 & & & & & & & 1 & & 3 & 81.5 \\
\hline 82.0 & 1 & & & & & & & 1 & 1 & & 1 & & & 1 & & 5 & 82.0 \\
\hline 82.5 & & & & & & & 1. & & & & & & & 1 & 1 & 3 & 82.5 \\
\hline 83.0 & 1 & & & & & & & & & & & & & & & 1 & 83.0 \\
\hline 83.5 & & & & & & & 2 & & & & 1 & & & 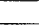 & & 3 & 83.5 \\
\hline 84.0 & & & & & & & & & & & & & 1 & & 1 & 2 & 84.0 \\
\hline 84.5 & & & & & & 2 & & & & & & 1 & 1 & 1 & & 5 & 84.5 \\
\hline 85.0 & 1 & 1 & & & 1 & 1 & & & 2 & & & 1 & 1 & & & 8 & 85.0 \\
\hline 85.5 & & & & & & & & & & & & & & & & & 85.5 \\
\hline 86.0 & 1 & 1 & & & & 1 & 2 & 1 & & 1 & & & & 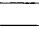 & & 7 & 86.0 \\
\hline 86.5 & & & & & & & 1 & 1 & & & & 1 & 1 & & & 4 & 86.5 \\
\hline 87.0 & & 2 & & & 1 & 2 & & & 1 & 1 & 1 & & & & 1 & 9 & 87.0 \\
\hline 87.5 & 1 & & & 1 & & 1 & & & 1 & 1 & & & & & & 5 & 87.5 \\
\hline 88.0 & 2 & 3 & & & & 1 & & & 3 & 1 & & 2 & 3 & & 1 & 16 & 88.0 \\
\hline 88.5 & & 3 & & & & & 1 & & & & 1 & 1 & & 1 & & 7 & 88.5 \\
\hline 89.0 & 1 & & 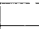 & 3 & 3 & & & 1 & 1 & 3 & 1 & 2 & 1 & & & 16 & 89.0 \\
\hline 89.5 & 1 & & - & & & & & & 1 & & & & & & 2 & 4 & 89.5 \\
\hline 90.0 & & & & 1 & 1 & & & & 2 & 2 & 2 & & 1 & & & 9 & 90.0 \\
\hline 90.5 & & & & 1 & 1 & & 1 & & 1 & 1 & 2 & 1 & 1 & & 1 & 10 & 90.5 \\
\hline 91.0 & 3 & 1 & 1 & $G$ & & & & 1 & 1 & 2 & 2 & 2 & 1 & 2 & 3 & 19 & 91.0 \\
\hline 91.5 & & 2 & & & 1 & & & & 2 & 1 & & & & & & 6 & 91.5 \\
\hline 92.0 & 1 & & 1 & 3 & 1 & & & 1 & 1 & 1 & 2 & & 1 & 1 & & 13 & 92.0 \\
\hline 92.5 & & 1 & 1 & 1 & 1 & & 1 & & & & & & & 2 & 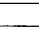 & 7 & 92.5 \\
\hline 93.0 & 1 & 1 & 1 & & 4 & & & & & 1 & & 1 & & 1 & & 10 & 93.0 \\
\hline 93.5 & & & & & & & & 1 & & & 1 & & & 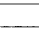 & & 2 & 93.5 \\
\hline 94.0 & & & & 2 & \begin{tabular}{|l|l|}
4 & \\
\end{tabular} & & & & & 2 & 3 & & & & 2 & 13 & 94.0 \\
\hline 94.5 & & & 2 & & 1 & & & & & & & & & 1 & 2 & 6 & 94.5 \\
\hline 95.0 & & & 2 & & & & & & & & & & & & 1 & 3 & 95.0 \\
\hline 95.5 & & & 2 & 1 & & & & & & & & 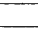 & & 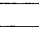 & & 3 & 95.5 \\
\hline 96.0 & & & & 1 & & & & & & & & & & & 1 & 2 & 96.0 \\
\hline 96.5 & & & & & \begin{tabular}{|l|l|}
1 & \\
\end{tabular} & & & & & & & & & & & 1 & 96.5 \\
\hline 97.0 & & 1 & & 1 & & & & & & & & & & & & 2 & 97.0 \\
\hline 97.5 & 1 & & & & & & & & & & & & & & & 1 & 97.5 \\
\hline 98.0 & & & & & & & & & & & & & & & & & 98.0 \\
\hline 98.5 & 1 & & & & & & & & & & & & & & & 1 & 98.5 \\
\hline 99.0 & & & & & & & & & & & & & & & & & 99.0 \\
\hline 99.5 & & & & & & & & & & & & & & & & & 99.5 \\
\hline 100.0 & & & & 1 & & & & & & & & & & & & 1 & 100.0 \\
\hline No.of Cars Tested & 16 & 16 & 10 & 17 & 20 & 13 & 12 & 8 & 18 & 17 & 18 & 12 & 12 & 12 & 16 & 217 & Total \\
\hline
\end{tabular}

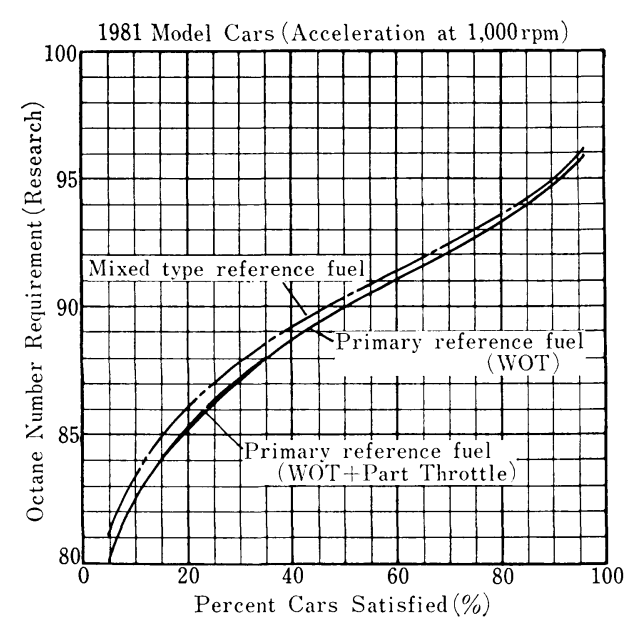

Fig. 1 Octane Number Requirement Curves

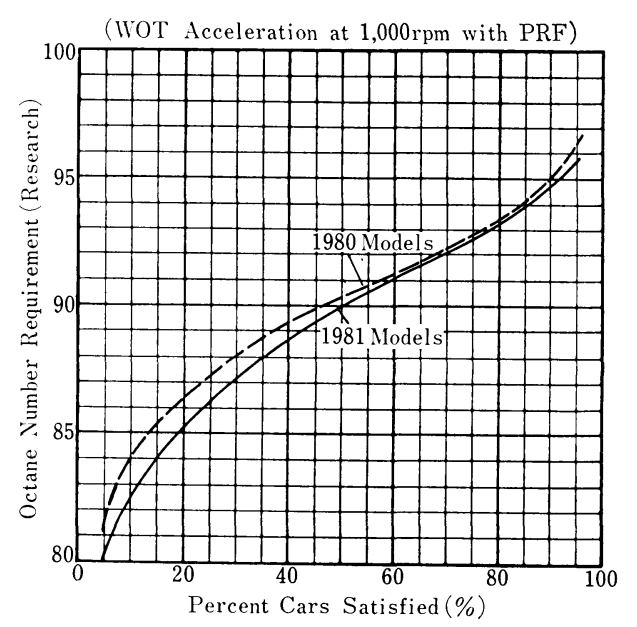

Fig. 2 Octane Number Requirement Curves, Comparison with 1980 Model Cars and 1981 Model Cars 
Table 6 Low Speed Octane Number Requirements Distribution

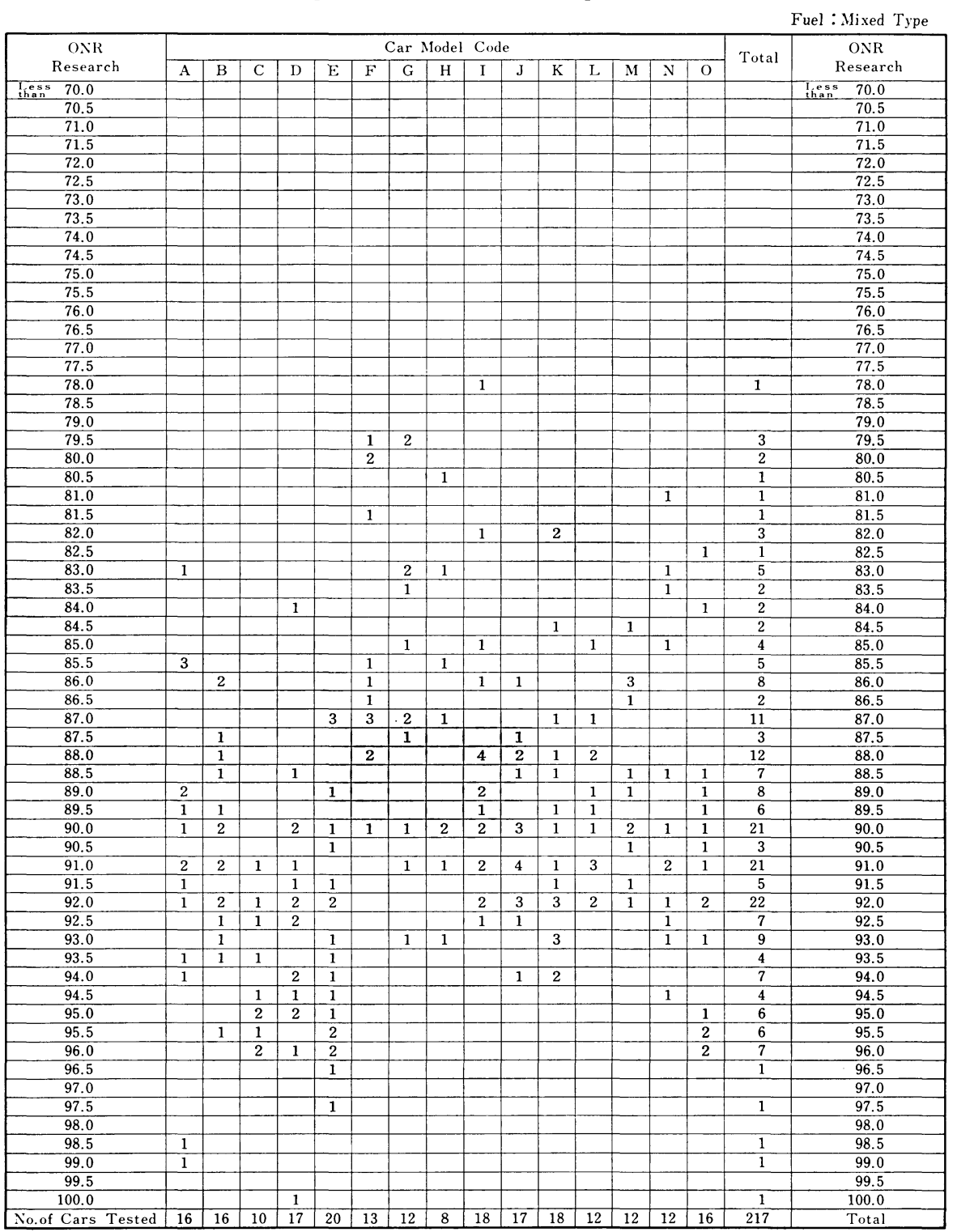

Table 7 Octane Number Requirement of 1981 Model Cars (Research Method)

\begin{tabular}{l|ccc}
\hline \multirow{3}{*}{ Reference Fuel } & \multicolumn{3}{l}{ Test Method Throttle Condition } \\
\cline { 2 - 4 } & $\begin{array}{l}\text { Low Speed Acceleration Wide } \\
\text { Open Throttle }\end{array}$ \\
\cline { 2 - 4 } & \multicolumn{3}{|c}{ Cars Satisfied \% } \\
\cline { 2 - 4 } & 10 & 50 & 90 \\
\hline $\begin{array}{l}\text { Primary Reference Fuel } \\
\text { Mixed Type }\end{array}$ & 82.4 & 90.0 & 94.7 \\
\hline
\end{tabular}

排気量別の低速法オクタン価要求值は $1,601 \sim 2,000 \mathrm{cc}$ の 車が他の区分の車に比べ低い值を示した。

\section{3 各標準燃料間の差}

各標準燃料間の差を Fig. 1 に示したオクタン価要求值から みると正標準燃料のオクタン価要求值は各充足率において混合
Table 8 Octane Number Reguirement of 1977 1981 Model Cars on PRF (Research Method)

\begin{tabular}{c|ccc}
\hline \multicolumn{2}{r}{$\begin{array}{r}\text { Test Method Throttle } \\
\text { Cars Condition }\end{array}$} & \multicolumn{3}{c}{$\begin{array}{c}\text { Low Speed Acceleration } \\
\text { Wide Open Throttle }\end{array}$} \\
\cline { 2 - 4 } Satisfied & 10 & 50 & 90 \\
\hline 1977 & 85.0 & 89.7 & 94.1 \\
1978 & 84.5 & 89.2 & 93.7 \\
1979 & 84.2 & 89.9 & 94.8 \\
1980 & 84.0 & 90.3 & 94.9 \\
1981 & 82.4 & 90.0 & 94.7 \\
\hline
\end{tabular}

系標準燃料より低い值を示し，その差は $0.3 \sim 1.1$ オクタンで あった。

$6 \cdot 4$ オクタン価要求值最高を示す吸入マニホールド負圧分 布

1981 年型全車のオクタン価要求值最高を示す吸入マニホー ルド負圧分布は Fig. 3 に示すよらに絞り弁全開加速が 97.6 


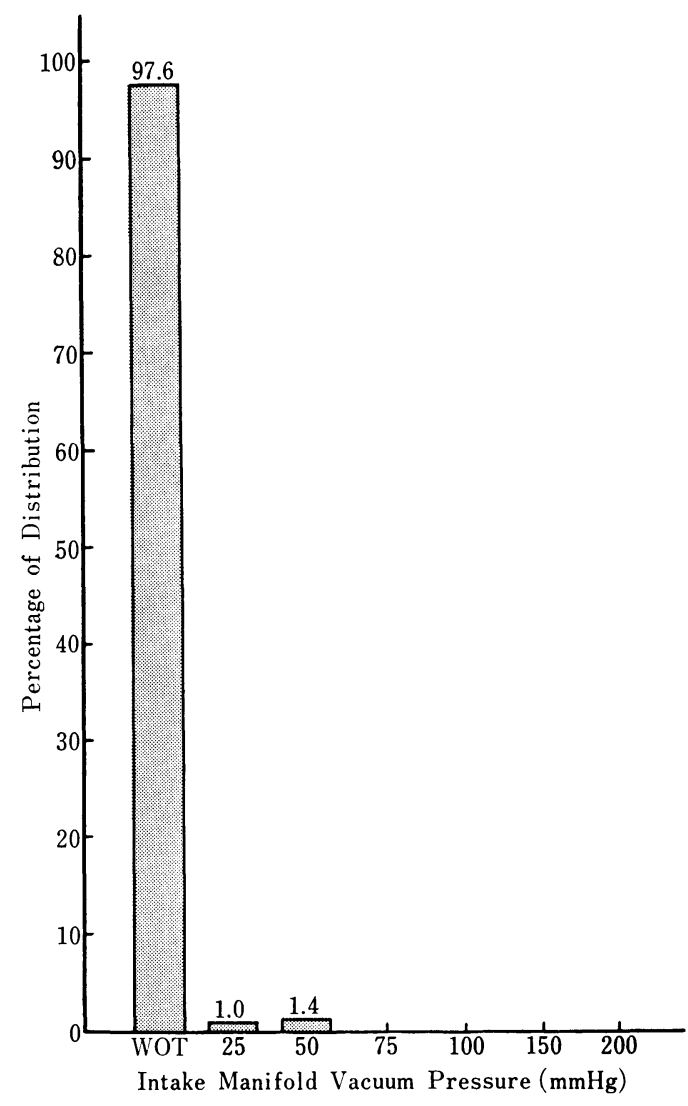

Fig. 3 Distribution of Intake Manifold Vaccum Pressure of Maximum ONR with PRF
\%と最も多く, 残り $2.4 \%$ は 25〜 $50 \mathrm{mmHg}$ の範囲に分布し ている。

\section{5 オクタン価要求値最高を示す速度分布}

1981 年型全車の絞り 弁全開加速に打けるオクタン価要求值 最高を示すェンジン回転速度分布を Fig. 4 に示す。オクタン 価要求値最高を示すェンジン回転速度は $1,000 \sim 4,050 \mathrm{rpm}$ 以 上の広い範囲に分布している。Table 10 で見られるように各 標準然料とも $1,000 \mathrm{rpm}$ でオクタン価要求值最高を示す車の 台数割合が減少し, 特に本年度は $3,050 \mathrm{rpm}$ 以上で最高を示 す車が増加した。

\section{7. 関係者（50 音順）}

製品部会長 木村元雄 (三菱石油)

ガソリン分科会委員長 仙洞田雍博 (出光興産)

オクタン価要求值専門委員会（本調查には以下の 19 機関が 参加した)

主查 三瀬一好（丸善石油）

幹事 太田健一 (日網石油精製)，大道勝利 (出光興産)，野 口岩男 (三菱石油), 野崎信義（日本石油），長谷川 豊（東亜 燃料工業)

委員 赤坂行男 (日本鉱業), 今市重道（モービル石油），岩 竹克己 (興亜石油), 榎本 豊 (昭和石油), 加藤敏明 (共同石 油), 熊倉昭夫 (アジア石油), 小林修一（鹿島石油), 佐藤浩 嗣 (エッソ石油), 芳賀 勝 (日本石油精製), 馬場征夫 (ゼネ ラル石油), 仏常正美 (キグナス石油), 森 堆育 (シェル石 油), 山田重久 (大協石油)

Table 9 Octane Number Requirement by Engine Displacement (Research Method)

Test Method : Low Speed Acceleration

\begin{tabular}{|c|c|c|c|c|c|c|}
\hline \multirow{4}{*}{ Engine Displacement } & \multicolumn{6}{|c|}{ Reference Fuels } \\
\hline & \multicolumn{3}{|c|}{ Primary Reference Fuel } & \multicolumn{3}{|c|}{ Mixed Type } \\
\hline & \multicolumn{6}{|c|}{ Cars Satisfied \% } \\
\hline & 10 & 50 & 90 & 10 & 50 & 90 \\
\hline $\begin{array}{l}1,601 \sim 2,000 \mathrm{cc} \\
1,301 \sim 1,600 \mathrm{cc} \\
\text { Smaller Than } 1,300 \mathrm{cc}\end{array}$ & $\begin{array}{l}81.5 \\
85.2 \\
87.7\end{array}$ & $\begin{array}{l}88.2 \\
90.5 \\
91.4\end{array}$ & $\begin{array}{l}93.8 \\
95.0 \\
94.5\end{array}$ & $\begin{array}{l}82.5 \\
85.4 \\
87.4\end{array}$ & $\begin{array}{l}89.0 \\
90.8 \\
91.7\end{array}$ & $\begin{array}{l}94.1 \\
95.3 \\
95.6\end{array}$ \\
\hline
\end{tabular}

Table 10 Trend of Engine Speeds for Maximum Octane Number Requirements under WOT Acceleration Condition

(Percentage of Cars Tested)

\begin{tabular}{|c|c|c|c|c|c|c|c|c|}
\hline \multirow{4}{*}{ Model Year } & \multicolumn{8}{|c|}{ Engine Speeds (rpm) } \\
\hline & \multicolumn{2}{|c|}{1,000} & \multicolumn{2}{|c|}{$1,050 \sim 2,000$} & \multicolumn{2}{|c|}{$2,050 \sim 3,000$} & \multicolumn{2}{|c|}{ More Than 3,050} \\
\hline & \multicolumn{8}{|c|}{ Reference Fuels } \\
\hline & PRF & Mixed Type & PRF & Mixed Type $\mid$ & PRF & Mixed Type & PRF & Mixed Type \\
\hline $\begin{array}{l}1977 \\
1978 \\
1979 \\
1980 \\
1981\end{array}$ & $\begin{array}{r}20.4 \\
13.2 \\
13.5 \\
14.0 \\
9.0\end{array}$ & $\begin{array}{l}19.4 \\
11.8 \\
15.2 \\
15.6 \\
11.9\end{array}$ & $\begin{array}{l}51.3 \\
54.4 \\
52.3 \\
48.2 \\
51.4\end{array}$ & $\begin{array}{l}47.8 \\
49.0 \\
42.7 \\
46.7 \\
44.9\end{array}$ & $\begin{array}{l}23.2 \\
21.4 \\
29.2 \\
30.2 \\
21.9\end{array}$ & $\begin{array}{l}20.9 \\
24.1 \\
31.1 \\
27.3 \\
22.5\end{array}$ & $\begin{array}{r}5.1 \\
6.5 \\
5.0 \\
7.6 \\
17.7\end{array}$ & $\begin{array}{l}11.9 \\
15.1 \\
11.0 \\
10.4 \\
20.7\end{array}$ \\
\hline
\end{tabular}




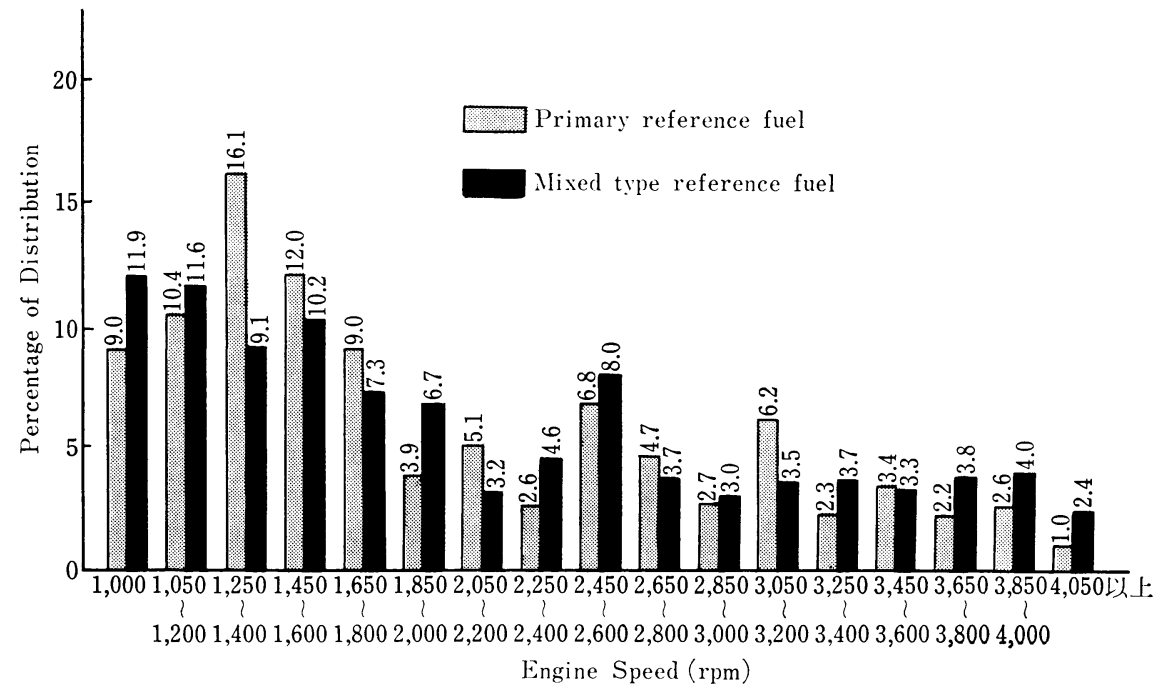

Fig. 4 Distribution of Engine Speed of Maximum ONR under WOT Acceleration at 1,000 rpm

\section{References}

1) The Sub-Committee of Octane Number Requirement Survey, Gasoline Division, Products Section or the Japan Petroleum Institute, Octane Number Requirement Survey of 1980 Japanese Model Passenger Cars, J. Japan Petrol. Inst, 24, (6), 396 (1981). 


\title{
Summary
}

\section{Octane Number Requirement Survey of 1981 Japanese Passenger Cars}

\author{
The Sub-Committee of Octane Number Requirement Survey, Gasoline \\ Division, Products Section of The Japan Petroleum Institute
}

The Sub-Committee of Octane Number Requirements (ONR) of the Japan Petroleum Institute has made a 1981 ONR survey on 120 Japanese Passenger Cars, including 47 automatic transmission cars, of 15 different models.

Since the 1975 ONR survey, the minimum mileage required to keep the stable ONR has been increased to over $6,000 \mathrm{~km}$.

Test vehicles and engine types are shown in Table 1.

Primary Reference Fuel (PRF) and Mixed Type of unlead Full Boiling Range Reference Fuel (FBRRF) have also been used as reference fuels.

The blending proportions for preparing the FBRRF and properties of the blending stocks are shown Tables 2 and $\mathbf{3}$, respectively.

The low speed knock indentifications was mainly carried out on the nine chassis dynamometers belonging to the participant companies and partly at the Test Track of the Japan Automobile Research Institute.

The road load of simulation of the chassis dynamometers was set arbitrarily by each participant but the inertia weight of the chassis dynamometer was set equal to the total vehicle weight.

The determination of knock was performed according to the JPI Standard Method 6R-6-77.

The low speed knock was identified in engine speed range from $1,000 \mathrm{rpm}$ to $4,000 \mathrm{rpm}$ during acceleration at the highest gear position.

The test results obtained were treated statistically according to the JPI Standard $6 \mathrm{R}-2-72$ in order to calculate the car satisfaction distribution for each of the given octane number fuels.

For these statistical data, ONRs of 97 cars surveyed in 1981 were incorpolated in the calculations, since the 1981 model year cars contain the similar to the 1980 model year car we have already tested.

These results are shown in Table 7 and illustrated in Fig. 1.

The low speed ONRs of 1981 model cars for $50 \%$ and $90 \%$ market satisfaction with the PRF were 90.0 and 94.7 octane numbers, respectively.

The ONR distributions of all the cars tested are summarized in Tables 5 and 6.

\section{Keywords}

Committee report, Japanese passenger car, Octane number requirement 